\title{
Correction to: Use of troponin assay after electrical injuries: a 15-year multicentre retrospective cohort in emergency departments
}

\author{
Delphine Douillet ${ }^{1,2^{*}} \mathbb{0}$, Stéphanie Kalwant ${ }^{3}$, Yara Amro ${ }^{1}$, Benjamin Gicquel ${ }^{3}$, Idriss Arnaudet ${ }^{3}$, \\ Dominique Savary ${ }^{1,2,3,4,5}$, Quentin Le Bastard ${ }^{3,4}$ and François Javaudin J $^{3,4}$
}

\section{Correction to: Scand J Trauma Resusc Emerg Med (2021) 29:141 https://doi.org/10.1186/s13049-021-00955-6}

Following the publication of the original article [1] the authors brought to our attention that their first and last names had unfortunately been interchanged.

The correct authors' names are shown in the author list of this Correction and have already been updated in the original article.

\section{Reference}

1. Douillet, et al. Use of troponin assay after electrical injuries: a 15-year multicentre retrospective cohort in emergency departments. Scand J Trauma Resusc Emerg Med. 2021;29:141. https://doi.org/10.1186/ s13049-021-00955-6.

\section{Publisher's Note}

Springer Nature remains neutral with regard to jurisdictional claims in published maps and institutional affiliations.

\begin{abstract}
Author details
'Département de Médecine d'Urgence, Centre Hospitalier Universitaire d'Angers, 4 rue Larrey, 49100 Angers, France. ${ }^{2}$ UMR MitoVasc CNRS 6015 - INSERM 1083, Health Faculty, Univ of Angers, FCRIN, INNOVTE, Angers, France. ${ }^{3}$ Emergency Department, Nantes University Hospital, Nantes, France. ${ }^{4}$ Microbiotas Hosts Antibiotics and Bacterial Resistances (MiHAR), University of Nantes, Nantes, France. ${ }^{5}$ EHESP, IrsetInserm, UMR S1085, CAPTV CDC, University of Rennes, Rennes, France.
\end{abstract}

Published online: 19 October 2021 original author(s) and the source, provide a link to the Creative Commons licence, and indicate if changes were made. The images or other third party material in this article are included in the article's Creative Commons licence, unless indicated otherwise in a credit line to the material. If material is not included in the article's Creative Commons licence and your intended use is not permitted by statutory regulation or exceeds the permitted use, you will need to obtain permission directly from the copyright holder. To view a copy of this licence, visit http://creativecommons.org/licenses/by/4.0/. The Creative Commons Public Domain Dedication waiver (http://creativecommons.org/publicdomain/zero/1.0/) applies to the data made available in this article, unless otherwise stated in a credit line to the data. 